\title{
Allocation pattern, photosynthetic performance and sugar metabolism in hydroponically grown seedlings of loquat (Eriobotrya japonica Lindl.) subjected to salinity
}

\author{
M.-I.N. SOTIRAS ${ }^{*}$, I.E. PAPADAKIS ${ }^{*,+}$, M. LANDI ${ }^{* *}$, G. TSANIKLIDIS ${ }^{* * *}$, P.I. TSIANTAS ${ }^{*}$, and \\ M. PSYCHOYOU****
}

Department of Crop Science, Agricultural University of Athens, Athens, Greece*

Department of Agriculture, Food \& Environment, University of Pisa, Pisa, Italy ${ }^{* *}$

Institute of Viticulture, Floriculture and Vegetable Crops of Heraklion, Hellenic Agricultural Organisation

"Demeter", Lycovrissi, Greece ${ }^{* * *}$

Department of Natural Resources Management \& Agricultural Engineering, Agricultural University of Athens, Athens, Greece ${ }^{* * * *}$

\begin{abstract}
Hydroponically grown loquat seedlings were subjected to increasing $\mathrm{NaCl}$ concentrations $(0,12,24$, and $48 \mathrm{mM})$ for $42 \mathrm{~d}$. At the whole plant level, $\mathrm{Na}^{+}$and $\mathrm{Cl}^{-}$accumulated proportionally to the salt treatments; however, $\mathrm{Na}^{+}$accumulated prevalently in leaves whilst $\mathrm{Cl}^{-}$accumulated prevalently in stems. Reduction of leaf biomass was only observed in seedlings grown with $48 \mathrm{mM} \mathrm{NaCl}$, whereas net photosynthesis declined along with increasing $\mathrm{NaCl}$ concentration and salinity led to general accumulation of glucose, reduction of mannitol and sorbitol, and changes in pigment composition in loquat leaves. Increasing level of salinity induced accumulations of both proline and $\mathrm{H}_{2} \mathrm{O}_{2}$ but not of malondialdehyde byproducts. Dramatic alteration of sugar patterns in the leaves poses serious concerns about possible effects of salinity to fruit production. Further research is necessary to investigate the concentration at which $\mathrm{NaCl}$ significantly compromises the yield of this economically important fruit species.
\end{abstract}

Additional key words: carotenoids; chlorophyll; gas exchange; NaCl; proline; salt stress.

\section{Introduction}

Loquat (Eriobotrya japonica Lindl.) is an evergreen fruit tree species belonging to the Rosaceae family (Lin et al. 2007) which is grown commercially in subtropical to mild temperate climates, including the Mediterranean area (García-Legaz et al. 2005, 2008). Salinity is one of the major abiotic stresses that affects plant growth and productivity in many arid and semiarid environments all over the world, including the major sites where loquat is cultivated, such as the Mediterranean basin (Chaves et al. 2009, Landi and Benelli 2016, Guidi et al. 2017). To date, there is insufficient data about the effect of salinity on the physiology/biochemistry of this species, though it has been observed that salinity can dramatically reduce photosynthetic performance (García-Legaz et al. 2005), alter antioxidant systems, and can seriously increase the level of oxidative stress (López-Gómez et al. 2007). In addition, there is a lack of knowledge about the sugar (and polyalcohol) metabolism and the pigment composition of salt-stressed loquat trees.

There are two main negative effects induced by a hypersaline environment on plant growth and development: water deficit and ion toxicity associated with excessive $\mathrm{Cl}^{-}$and $\mathrm{Na}^{+}$(Chaves et al. 2009, Shabala and Munns 2012). Impairment of photosynthetic performance under salt stress is firstly a consequence of stomatal limitations induced by the osmotic stress perceived by the leaf when plants are grown in a hypersaline environment (Shabala and Munns 2012). Under these circumstances, there is a limited $\mathrm{CO}_{2}$ availability, as well as the accumulation of ATP and NADH, which leads to an excess of excitation energy (Takahashi and Badger 2011). As a consequence, the deregulation of the cellular metabolism can cause an increase in rates of the reactive oxygen species (ROS) production. Indeed, ROS accumulation is one of the most

Received 3 May 2018, accepted 16 July 2018.

+Corresponding author; phone: 003021052945 90, fax. 003021052945 90, e-mail: papadakis@aua.gr

Abbreviations: $\mathrm{Car}$ - carotenoids; $\mathrm{Chl}$ - chlorophyll; $C_{\mathrm{i}}$ - intercellular $\mathrm{CO}_{2}$ concentration; $E$ - transpiration; $g_{\mathrm{s}}-$ stomatal conductance; MDA - malondialdehyde; $P_{\mathrm{N}}$ - net photosynthesis; ROS - reactive oxygen species; TBA - 2-thiobarbituric acid; TCA - trichloroacetic acid; WUE - water-use efficiency.

Acknowledgements: The authors would like to thank Mr. Nikitas Migklis for providing technical assistance during the hydroponic cultivation of plants. 
frequently observed reactions in salt-treated plants (Parihar et al. 2015), including loquat seedlings (Hernández et al. 2003), which can trigger oxidative damage to the chloroplasts (Triantaphylidès and Havaux 2009). Metabolic limitations of photosynthesis in plants affected by salinity can also be a result of harmful concentrations of $\mathrm{Na}^{+}$ and $\mathrm{Cl}^{-}$in the leaf tissue (Munns et al. 2006). In some species, $\mathrm{Cl}^{-}$accumulation significantly impairs the photosynthetic process (Tavakkoli et al. 2010), whereas ion excess (both $\mathrm{Na}^{+}$and $\mathrm{Cl}^{-}$) induces a reduction of leaf expansion as a consequence of reduced leaf transpiration rate. In turn, this results into a surplus of photosynthates in actively growing tissues (Munns et al. 2000). Excess of photosynthates induces feedback signals which downregulate the photosynthesis to compensate the lower sugar demand due to the temporary inhibition of plant growth, even if in some cases sugar accumulation can occur before feed-back regulatory mechanisms take place (Lemoine et al. 2013). Furthermore, the accumulation of $\mathrm{Na}^{+}$and $\mathrm{Cl}^{-}$ at cytosolic or chloroplast level inhibits the activity of photosynthesis-related enzymes, thereby further reducing $\mathrm{CO}_{2}$ photoassimilation (Sudhir and Murthy 2004).

Responses of plants to high salinity encompass a plethora of mechanisms at both biochemical and physiological levels, such as the control/exclusion of ion uptake by roots and transport into leaves, the compartmentalization of ions at the cellular and organ levels, the change in photosynthetic pathway, the alteration in membrane structure, the induction of antioxidant systems, stimulation of plant hormones, and the synthesis of compatible solutes including proline and sugars (sensu lato including polyols) (Sudhir and Murthy 2004, Parida and Das 2005). In plants grown under high salinity conditions, these metabolites can indeed act as osmoprotectants (Gupta and Huang 2014), whereas proline can also play a key role in the stabilization of proteins and protein complexes in the chloroplast and cytosol, and in the protection of the photosynthetic apparatus (as shown in the salt-hypersensitive p5cs1 Arabidopsis mutant) (Szabados and Savouré 2010).

The aim of the present research was thus to: (1) characterize the allometric responses of loquat organs to prolonged salinity exposure, as well as the allocation pattern of ions mainly perturbed by salinity stress $\left(\mathrm{Na}^{+}, \mathrm{Cl}^{-}\right.$, and $\left.\mathrm{K}^{+}\right)$, and (2) determine the photosynthetic responses and changes in pigment and carbon metabolism of loquat saplings subject to increasing levels of salinity.

\section{Materials and methods}

Plant material and growth conditions: Six-month-old seedlings of E. japonica, uniform in stem diameter, leaf area, and height, were initially grown in black plastic pots containing a mixture of peat:perlite $(2: 1, \mathrm{v} / \mathrm{v})$ at a glasshouse located at the arboretum of the Agricultural University of Athens (latitude 37.981907, longitude 23.705639).
Afterward, the plants were individually transplanted into black plastic bags containing 21 of a mixture of silica sand:perlite (1:2, v/v) for $21 \mathrm{~d}$ (acclimation period). During transplanting, the seedling roots were thoroughly washed firstly with tap water and then with distilled water in order to remove residuals of the initial mixture. During the acclimation period, loquat seedlings were irrigated three times per week with tap water. Afterwards, the plants were irrigated, thrice per week, with a full-strength Hoagland's nutrient solution, differing in $\mathrm{NaCl}$ concentration ( 0 , 12,24 , and $48 \mathrm{mM}$ ). In total, 20 plants were used (five replicates per each $\mathrm{NaCl}$ treatment). During the growing period, maximum and minimum average temperatures were $28.8 \pm 4.7^{\circ} \mathrm{C}$ and $19.9 \pm 2.7^{\circ} \mathrm{C}$, respectively. The irradiance averaged $580 \mu \mathrm{mol}$ (quantum) $\mathrm{m}^{-2} \mathrm{~s}^{-1}$.

One week after the appearance of the initial mild visible symptoms of salinity stress (in the form of yellow-brown necrosis on the leaf margin; see Fig. 1S - supplement) in basal leaves of seedlings grown under $48 \mathrm{mM} \mathrm{NaCl}$, i.e., $41 \mathrm{~d}$ after $\mathrm{NaCl}$ imposition, gas-exchange parameters were measured (details below). The next day, the third and the fourth fully-expanded mature leaf from the top to the base of the shoot (not symptomatic; completely developed under the salt treatment), were sampled for biochemical determinations. After the measurement of the number of leaves and their total area per plant, including the leaves sampled for the aforementioned determinations, each plant part was weighted (FM), washed initially with tap water and afterwards twice with distilled water. Finally, all plant parts were oven-dried at $75^{\circ} \mathrm{C}$ until they become a constant mass (DM).

$\mathrm{Na}^{+}, \mathrm{Cl}^{-}$and $\mathrm{K}^{+}$concentration in plant organs: Dried plant parts were milled to a fine powder. The concentrations of $\mathrm{Na}^{+}, \mathrm{Cl}^{-}$, and $\mathrm{K}^{+}$were determined in all plant parts. For measurements of $\mathrm{K}^{+}$and $\mathrm{Na}^{+}$, dried powder $(0.5 \mathrm{~g})$ of each sample was ashed for $5.5 \mathrm{~h}$ at $550^{\circ} \mathrm{C}$, dissolved in $3 \mathrm{ml}$ of $6 \mathrm{~N} \mathrm{HCl}$ and diluted with deionized water up to $50 \mathrm{ml}$. Then, $\mathrm{K}^{+}$and $\mathrm{Na}^{+}$concentrations were measured using a flame spectrophotometer (PGI 2000, PG Instruments Ltd., Alma Park-Leicestershire, UK) standard methods. For $\mathrm{Cl}^{-}$ analysis, dried powder $0.2 \mathrm{~g}$ of each plant part was weighed and put in falcon tubes containing $25 \mathrm{ml}$ of deionized water and were continuously shaken for $24 \mathrm{~h}$. Then a centrifugation $(4,400 \times g$ for $15 \mathrm{~min}$ at room temperature) was carried out, and afterwards the supernatant was further filtered by using lab filter paper. $\mathrm{Cl}^{-}$concentration was determined after titration with $0.0141 \mathrm{~N} \mathrm{AgNO}_{3}$ using the 702 SM Titrino potentiometric automatic titrator (Metrohm $A G$, Herisau, Switzerland).

Chlorophyll (Chl) and carotenoid (Car) content: Fresh leaf samples $(75 \mathrm{mg})$ were ground in a mortar with $10 \mathrm{ml}$ of cold acetone $(80 \%)$, transferred in falcon tubes, kept in the dark for $1 \mathrm{~h}$, and vortexed at 15-min intervals. A 
centrifugation at $4,400 \times g$ for 5 min at $4{ }^{\circ} \mathrm{C}$ was then performed. Chl and Car concentrations were determined spectrophotometrically at absorbance of 470, 647, and 663 $\mathrm{nm}$ and using the equation described by Lichtenthaler and Buschmann (2001):

$$
\begin{aligned}
& {[\mathrm{Chl} a]=12.25 \mathrm{~A}_{663}-2.79 \mathrm{~A}_{647}} \\
& {[\mathrm{Chl} b]=21.5 \mathrm{~A}_{647}-5.1 \mathrm{~A}_{663}} \\
& {[\mathrm{Car}]=\left\{1000 \mathrm{~A}_{470}-1.82[\mathrm{Chl} a]-85.02[\mathrm{Chl} b]\right\} / 198}
\end{aligned}
$$

Sugar, sorbitol, mannitol, and starch: For soluble carbohydrates determination, $30 \mathrm{mg}$ of freeze-dried leaf tissue were added to $2 \mathrm{ml}$ of HPLC grade water (Carlo Erba Reagents S.A.S, Val-de-Reuil, France) and vortexed for $20 \mathrm{~s}$. Then extraction of the water-soluble carbohydrates was performed in a microwave oven for 2 min at $400 \mathrm{~W}$. After centrifugation $\left(4,400 \times g\right.$ for $10 \mathrm{~min}$ at $\left.4^{\circ} \mathrm{C}\right)$, the supernatant was removed and this process was repeated. The two supernatants were pooled together and filtered using syringe filters $(0.2 \mu \mathrm{m}$ pore size). HPLC analyses were conducted using a HPLC pump (model 510 Waters, Milford, MA, USA) equipped with an HP refractive indexRI (HP 1047A, HP, Palo Alto, CA, USA). The mobile phase consisted of HPLC grade water. Twenty $\mu$ l of extract was injected into an Agilent HI-PLEX $\mathrm{Ca}^{2+}$ column $(7.7 \times$ $300 \mathrm{~mm}, 8 \mu \mathrm{m}$, mobile phase: $100 \%$ DI $\mathrm{H}_{2} \mathrm{O}$, flow rate of $0.6 \mathrm{ml} \mathrm{min}{ }^{-1}$, temperature of $80^{\circ} \mathrm{C}$, detector: refractive index) (Agilent, Santa Clara, CA, USA). The processing of the chromatograms was conducted by means of PeakSimple chromatograpy data system consisted of a hardware (Model 302, SRI Instruments, Bad Honnef, Germany) and the PeakSimple 4.51 chromatography acquisition and integration software for Windows (SRI Instruments, Bad Honnef, Germany). Sucrose, glucose, fructose, sorbitol, and mannitol quantitative determination was based on a specific reference curve with HPLC pure grade standards. The concentration of starch in loquat leaves was measured according to the procedure described by Vemmos (1999).

Determination of lipid peroxidation and $\mathbf{H}_{2} \mathbf{O}_{2}$ : Leaf tissue $(0.5 \mathrm{~g}$ FM) was homogenized in $10 \mathrm{ml} 0.1 \%$ trichloroacetic acid (TCA) at $4^{\circ} \mathrm{C}$. After centrifugation at $4,400 \times g$ for $15 \mathrm{~min}$ at $4^{\circ} \mathrm{C}$, the supernatant was used for the determination of both lipid peroxidation level and $\mathrm{H}_{2} \mathrm{O}_{2}$ concentration. Lipid peroxidation was measured as malondialdehyde (MDA) byproduct content determined by reaction with $0.5 \%$ 2-thiobarbituric acid in 20\% TCA $(\mathrm{w} / \mathrm{v})$. The concentration of MDA was calculated from the difference of the absorbance at 532 and $600 \mathrm{~nm}$ using the extinction coefficient of $155 \mathrm{mmol}^{-1} \mathrm{~cm}^{-1}$ (Heath and Packer 1968). Hydrogen peroxide was also measured spectrophotometrically after a reaction with potassium iodide $(\mathrm{KI})$. The reaction mixture consisted of $0.5 \mathrm{~mL}$ of $0.1 \%$ TCA, leaf extract supernatant, $0.5 \mathrm{ml}$ of $0.1 \mathrm{M}$ potassium-phosphate buffer ( $\mathrm{pH} 7)$, and $1 \mathrm{ml}$ of $1 \mathrm{M} \mathrm{KI}$ $(\mathrm{w} / \mathrm{v})$. The reaction color was developed within $45 \mathrm{~min}$ in darkness and absorbance was measured at $390 \mathrm{~nm}$ (Spectronic Helios Gamma UV-VIS, Thermo Fisher Scientific, UK) The amount of hydrogen peroxide was calculated using a standard curve prepared with eight known concentrations of $\mathrm{H}_{2} \mathrm{O}_{2}$.

Proline estimation: Fresh leaves $(0.1 \mathrm{~g})$ were cut into small pieces and ground with a mortar with $10 \mathrm{ml}$ of $80 \%$ $(\mathrm{v} / \mathrm{v})$ ethanol. The homogenate was placed in falcon tubes and then centrifuged at $4,400 \times g$ for $5 \mathrm{~min}$ at $4^{\circ} \mathrm{C}$. One milliliter of the supernatant was transferred into test tubes containing $2 \mathrm{ml}$ of acid-ninhydrin. After mixing, test tubes were maintained at $95^{\circ} \mathrm{C}$ for $25 \mathrm{~min}$ in a water bath and then transferred to an ice bath and allowed to cool at room temperature. After centrifugation $(5 \mathrm{~min}$ for $4,400 \times g$ at $4^{\circ} \mathrm{C}$ ), the absorption of the supernatant was recorded at $520 \mathrm{~nm}$ (Spectronic Helios Gamma UV-VIS, Thermo Fisher Scientific, UK) and proline was quantified as described by Bates et al. (1973).

Gas-exchange parameters were measured using a portable $\mathrm{Li}$-Cor 6400 ( $\mathrm{Li}$-Cor, Lincoln, NE, USA) infrared gas analyzer. Net photosynthetic (assimilation) rate $\left(P_{\mathrm{N}}\right)$, stomatal conductance $\left(g_{\mathrm{s}}\right)$, transpiration rate $(E)$, and intercellular $\mathrm{CO}_{2}$ concentration $\left(C_{\mathrm{i}}\right)$ were measured twice per plant and per $\mathrm{NaCl}$ treatment, using both the $3^{\text {rd }}$ and $4^{\text {th }}$ fully developed leaves from the shoot apex. To avoid the effects of fluctuating environments on gas-exchange measurements, all plants were measured between 9:50 and 11:15 h (GMT), under steady-state light intensity [1,200 $\mu$ mol(quantum) $\left.\mathrm{m}^{-2} \mathrm{~s}^{-1}\right]$ and $\mathrm{CO}_{2}$ concentration (390 $\mathrm{mg} \mathrm{l}^{-1}$ ), while the leaf temperature ranged between 28.1 and $29.6^{\circ} \mathrm{C}$. Intrinsic water-use efficiency $\left(\mathrm{WUE}_{\mathrm{i}}\right)$ was calculated as $P_{\mathrm{N}} / g_{\mathrm{s}}$, whereas instantaneous WUE was calculated as $P_{\mathrm{N}} / E$. Carbon dioxide-use efficiency was estimated as $P_{\mathrm{N}} / C_{\mathrm{i}}$.

Statistical analysis: Homogeneity of variance was assessed by Bartlett's test and then the data were subjected to one-way analysis of variance ( $A N O V A$ ) using the ' $P A S W$ Statistics 18' statistical package (SPSS INC., Chicago, IL, USA). Percentage values were arcsine transformed prior to analyses. For mean separation, the Tukey's multiple range post-hoc test was applied $(P \leq 0.05)$. Linear correlations were calculated using the Pearson's correlation test using GraphPad (La Jolla, CA, USA). The experiments were arranged following a completely randomized experimental design.

\section{Results}

Dry mass partitioning and biometric parameters: After $42 \mathrm{~d}$ of $\mathrm{NaCl}$ treatment, the salt-treated plants maintained similar stem biomass production, independently of the $\mathrm{NaCl}$ concentration imposed (Table 1). Increased root DM was observed in salt-treated plants, even though the 
Table 1. Biometric parameters of Eriobotrya japonica seedlings grown under control ( $0 \mathrm{mM})$ and excess of $\mathrm{NaCl}(12,24,48 \mathrm{mM})$ for 42 days. Means $(n=5 \pm \mathrm{SE})$ with different letters are different after one-way ANOVA followed by multiple range Tukey's post-hoc test $(P \leq 0.05)$.

\begin{tabular}{|c|c|c|c|c|}
\hline \multirow[t]{2}{*}{ Parameter } & \multicolumn{4}{|l|}{$\mathrm{NaCl}[\mathrm{mM}]$} \\
\hline & 0 & 12 & 24 & 48 \\
\hline $\begin{array}{l}\text { Leaves } \\
{[\mathrm{g}(\mathrm{DM}) \text { per plant }]}\end{array}$ & $6.18 \pm 0.32^{b}$ & $7.13 \pm 0.38^{b}$ & $6.91 \pm 0.41^{\mathrm{b}}$ & $5.37 \pm 0.45^{\mathrm{a}}$ \\
\hline Stem $[\mathrm{g}(\mathrm{DM})$ per plant $]$ & $1.68 \pm 0.13^{\mathrm{a}}$ & $1.44 \pm 0.14^{\mathrm{a}}$ & $1.77 \pm 0.14^{\mathrm{a}}$ & $1.60 \pm 0.17^{\mathrm{a}}$ \\
\hline Root [g(DM) per plant] & $1.64 \pm 0.13^{\mathrm{a}}$ & $1.86 \pm 0.14^{\mathrm{a}}$ & $1.93 \pm 0.15^{\mathrm{a}}$ & $1.74 \pm 0.15^{\mathrm{a}}$ \\
\hline Total $[\mathrm{g}(\mathrm{DM})$ per plant $]$ & $9.43 \pm 0.55^{\mathrm{a}}$ & $10.43 \pm 0.67^{a}$ & $10.60 \pm 0.66^{\mathrm{a}}$ & $8.71 \pm 0.66^{\mathrm{a}}$ \\
\hline Shoot/root & $4.81 \pm 0.19^{\mathrm{a}}$ & $5.55 \pm 0.34^{\mathrm{a}}$ & $6.00 \pm 0.47^{\mathrm{a}}$ & $5.17 \pm 0.48^{\mathrm{a}}$ \\
\hline Leaf area $\left[\mathrm{cm}^{2}\right.$ per leaf $]$ & $72.95 \pm 6.20^{\mathrm{a}}$ & $67.10 \pm 2.77^{\mathrm{a}}$ & $73.47 \pm 9.80^{\mathrm{a}}$ & $76.48 \pm 12.98^{\mathrm{a}}$ \\
\hline Leaf number & $11.25 \pm 0.63^{\mathrm{b}}$ & $12.00 \pm 0.41^{\mathrm{b}}$ & $12.00 \pm 0.41^{\mathrm{b}}$ & $9.50 \pm 0.65^{\mathrm{a}}$ \\
\hline Plant leaf area $\left[\mathrm{cm}^{2}\right]$ & $817.6 \pm 69.7^{\mathrm{b}}$ & $796.3 \pm 118.4^{\mathrm{b}}$ & $872.9 \pm 100.2^{\mathrm{b}}$ & $704.5 \pm 72.1^{\mathrm{a}}$ \\
\hline
\end{tabular}

Table 2. $\mathrm{Na}^{+}, \mathrm{Cl}^{-}$, and $\mathrm{K}^{+}$concentration $[\%(\mathrm{DM})]$ as well as $\mathrm{K}^{+} / \mathrm{Na}^{+}$ratio in leaves, stem and roots of Eriobotrya japonica seedlings grown under control $(0 \mathrm{mM})$ and excess of $\mathrm{NaCl}(12,24,48 \mathrm{mM})$ for 42 days. Means $(n=5 \pm \mathrm{SE})$ with different letters are different after one-way ANOVA followed by multiple range Tukey's post-hoc test $(P \leq 0.05)$.

\begin{tabular}{lllll}
\hline Parameter & $\mathrm{NaCl}[\mathrm{mM}]$ & & \\
& 0 & 12 & 24 & 48 \\
\hline $\mathrm{Na}^{+}$leaves [\% DM] & $0.09 \pm<0.01^{\mathrm{a}}$ & $0.23 \pm<0.01^{\mathrm{b}}$ & $0.51 \pm 0.03^{\mathrm{c}}$ & $0.73 \pm 0.09^{\mathrm{d}}$ \\
$\mathrm{Na}^{+}$stem [\% DM] & $0.08 \pm<0.01^{\mathrm{a}}$ & $0.13 \pm 0.02^{\mathrm{b}}$ & $0.14 \pm 0.02^{\mathrm{b}}$ & $0.20 \pm 0.01^{\mathrm{c}}$ \\
$\mathrm{Na}^{+}$roots [\% DM] & $0.11 \pm 0.02^{\mathrm{a}}$ & $0.21 \pm 0.01^{\mathrm{b}}$ & $0.30 \pm 0.04^{\mathrm{c}}$ & $0.57 \pm 0.09^{\mathrm{d}}$ \\
$\mathrm{Cl}^{-}$leaves [\% DM] & $0.03 \pm<0.01^{\mathrm{a}}$ & $0.04 \pm<0.01^{\mathrm{a}}$ & $0.12 \pm 0.02^{\mathrm{b}}$ & $0.24 \pm 0.03^{\mathrm{c}}$ \\
$\mathrm{Cl}^{-}$stem [\% DM] & $0.09 \pm<0.01^{\mathrm{a}}$ & $0.11 \pm 0.01^{\mathrm{a}}$ & $0.32 \pm 0.03^{\mathrm{b}}$ & $0.45 \pm 0.03^{\mathrm{c}}$ \\
$\mathrm{Cl}^{-}$roots [\%DM] & $0.11 \pm 0.01^{\mathrm{a}}$ & $0.61 \pm 0.1^{\mathrm{b}}$ & $0.63 \pm 0.01^{\mathrm{b}}$ & $0.81 \pm 0.07^{\mathrm{c}}$ \\
$\mathrm{K}^{+}$leaves [\% DM] & $2.55 \pm 0.15^{\mathrm{a}}$ & $2.46 \pm 0.10^{\mathrm{a}}$ & $2.27 \pm 0.18^{\mathrm{a}}$ & $2.36 \pm 0.62^{\mathrm{a}}$ \\
$\mathrm{K}^{+}$stem [\% DM] & $2.74 \pm 0.11^{\mathrm{a}}$ & $2.14 \pm 0.75^{\mathrm{a}}$ & $2.21 \pm 0.13^{\mathrm{a}}$ & $2.30 \pm 0.22^{\mathrm{a}}$ \\
$\mathrm{K}^{+}$roots [\% DM] & $2.27 \pm 0.21^{\mathrm{a}}$ & $2.10 \pm 0.20^{\mathrm{a}}$ & $2.66 \pm 0.14^{\mathrm{a}}$ & $2.54 \pm 0.10^{\mathrm{a}}$ \\
$\mathrm{K}^{+} / \mathrm{Na}^{+}$leaves & $28.0 \pm 1.2^{\mathrm{d}}$ & $11.0 \pm 0.6^{\mathrm{c}}$ & $4.5 \pm 0.3^{\mathrm{b}}$ & $3.5 \pm 0.5^{\mathrm{a}}$ \\
$\mathrm{K}^{+} / \mathrm{Na}^{+}$stem & $35.9 \pm 1.7^{\mathrm{c}}$ & $18.4 \pm 2.8^{\mathrm{b}}$ & $16.2 \pm 1.6^{\mathrm{b}}$ & $11.9 \pm 0.9^{\mathrm{a}}$ \\
$\mathrm{K}^{+} / \mathrm{Na}^{+}$roots & $22.2 \pm 3.3^{\mathrm{c}}$ & $10.3 \pm 1.2^{\mathrm{b}}$ & $9.5 \pm 1.2^{\mathrm{b}}$ & $4.8 \pm 0.6^{\mathrm{a}}$ \\
\hline
\end{tabular}

difference was not significant (Table 1). Of note, the root apparatus was the only organ in which a significant increase of moisture content was recorded $(\sim+3 \%$ on average than controls; data not shown). Conversely, we observed a reduction of leaves DM only at the highest $\mathrm{NaCl}$ concentration (6.2 vs. 5.4 g per plant in controls and plants treated with $48 \mathrm{mM}$ of $\mathrm{NaCl}$, respectively). This reduction was attributable to the reduced number of leaves of the $48 \mathrm{mM}$-salt-treated plants, which correlates with a reduced leaf area per plant ( $-14 \%$ with respect to controls) (Table 1). No significant changes were observed between controls and salt-treated plants in terms of shoot/root ratio (Table 1).

Partitioning of $\mathrm{Na}^{+}, \mathrm{Cl}^{-}$and $\mathrm{K}^{+}$between plant organs: $\mathrm{Na}^{+}$and $\mathrm{Cl}^{-}$accumulation paralleled the severity of salt treatment (Table 2) and significant linear correlations were found between $\mathrm{NaCl}$ supply against $\mathrm{Na}^{+} / \mathrm{Cl}^{-}$accumulated in different plant organs (Fig. $1 A, B$ ). Even though $\mathrm{Na}^{+}$and $\mathrm{Cl}^{-}$accumulated with a similar extent at the whole plant level, at each salt treatment (e.g., at $48 \mathrm{mM}, \mathrm{Na}^{+}$and $\mathrm{Cl}^{-}$ averaged 0.50 and $0.42 \% \mathrm{DM}$, respectively), $\mathrm{Na}^{+}$and $\mathrm{Cl}^{-}$had different patterns of distribution to different plant organs. $\mathrm{Na}^{+}$accumulated principally in leaves, then in roots and stems (slope of linear correlation was 0.013, 0.0095, and 0.0024 , respectively), whereas $\mathrm{Cl}^{-}$accumulation occurred preferentially in roots followed by stems and leaves (slope of linear correlation was $0.013,0.008$, and 0.004 , respectively). Of note, linear correlation between $\mathrm{NaCl}$ supply and $\mathrm{Cl}^{-}$accumulation in roots (Fig. $1 B$ ) only had a $r^{2}$ of 0.74 due to the high variability observed in $\mathrm{Cl}^{-}$accumulation at $12 \mathrm{mM} \mathrm{NaCl}$. Roots accumulated proportionally more $\mathrm{Cl}^{-}$than $\mathrm{Na}^{+}$at $48 \mathrm{mM} \mathrm{NaCl}$, whereas the accumulation of both $\mathrm{Na}^{+}$and $\mathrm{Cl}^{-}$in leaves was similar under the same treatment $(\sim 8$-fold higher than controls for both the elements). No differences were found regarding $\mathrm{K}^{+}$partitioning, even though the ratio of $\mathrm{K}^{+} / \mathrm{Na}^{+}$decreased severely along with $\mathrm{NaCl}$ treatments, with the highest decrement observed in leaves, followed by roots and stems (Table 2). 


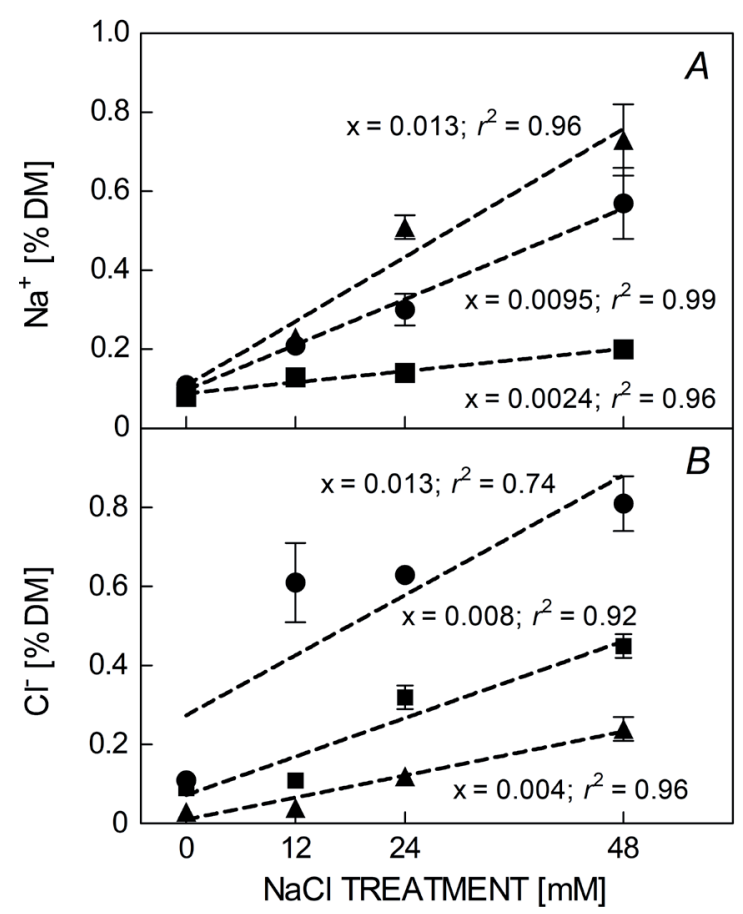

Fig. 1. Linear relation between increasing concentrations of $\mathrm{NaCl}$ in the nutrient solution $(0,12,24$, and $48 \mathrm{mM}) v s$. $(A) \mathrm{Na}^{+}$and (B) $\mathrm{Cl}^{-}$concentration [\% (DM)] in leaves (triangle), stem (circle), roots (square) of Eriobotrya japonica. Linear correlations were tested using Pearson's correlation test $(P \leq 0.05)$. Coefficient of determination $\left(r^{2}\right)$ and equation slope $(\mathrm{x})$ were reported.

Sugar metabolism in leaves: At the end of the experimental period, we observed a strong accumulation of glucose, independent of the severity of salt treatment (from $0.24-0.44,0.56,0.52 \%$ in plants grown with 0 , 12,24 , and $48 \mathrm{mM} \mathrm{NaCl}$, respectively) (Table 3). These increments led to higher contents of nontranslocated sugars in the leaves, given that the concentration of fructose was mostly constant regardless of the level of imposed salinity. Conversely, we observed a general decline of sucrose and other translocating polyols (mannitol and sorbitol, which are typical of loquat) but these decrements were not consistent with the severity of salinity. In fact, plants grown with $12 \mathrm{mM} \mathrm{NaCl}$ exhibited the lowest foliar concentration of total sugars, which is dependent on the strongest reduction of sorbitol, as evidenced by the lowest concentration of translocated sugars observed in plants belonging to this treatment. The ratio between translocated to non-translocated sugars was approximately 50\% lower in salt-treated plants, consistently at each salt level. No significant changes were observed between controls and treated plants in terms of starch amount (Table 3).

Pigment composition: Plants grown under salinity showed a lower content of total $\mathrm{Chl}$ than that of controls, even though we did not observe a reduction of Chl $b$ at any salt treatment, and only a significant decline of Chl $a$ was observed in plants submitted to the most severe salt treatment (Fig. 2A). A consistent reduction of $\mathrm{Chl} a / b$ ratio was observed at all the $\mathrm{NaCl}$ concentrations (Fig. 2B), whereas no significant variations were observed in Car contents (Fig. 2C).

$\mathrm{H}_{2} \mathrm{O}_{2}$, MDA and proline accumulation: Higher contents of $\mathrm{H}_{2} \mathrm{O}_{2}$ were observed in leaves of salt-treated plants, with the highest accumulation shown by plants grown at $48 \mathrm{mM}$ $\mathrm{NaCl}\left[1.82\right.$ in controls vs. 1.95, 2.32, and $3.11 \mu \mathrm{mol} \mathrm{g}^{-1}(\mathrm{FM})$ at 12, 24 and $48 \mathrm{mM} \mathrm{NaCl}$, respectively] (Fig. 3A). No differences were observed between plants grown at 12 and $24 \mathrm{mM} \mathrm{NaCl}$ concerning leaf $\mathrm{H}_{2} \mathrm{O}_{2}$ content. No significant differences in MDA byproduct contents were found between controls and salt-treated plants (Fig. 3B), whilst leaves of salt-treated plants had higher content of proline

Table 3. Concentrations of glucose (Glu), fructose (Fru), sucrose (Suc), mannitol, (Man), sorbitol, (Sorb), total sugars (Suc + Glu $+\mathrm{Fru}+\mathrm{Man}+\mathrm{Sorb})$, translocated sugars (Suc + Man + Sorb), nontranslocated sugars (Fru + Glu), the ratios between translocated/ nontranslocated, translocated/total, nontranslocated/total, and starch content in Eriobotrya japonica seedlings grown under control $(0 \mathrm{mM})$ and excess of $\mathrm{NaCl}(12,24$, and $48 \mathrm{mM})$ for 42 days. Means $(n=5 \pm \mathrm{SE})$ with different letters are different after one-way ANOVA followed by multiple range Tukey's post-hoc test $(P \leq 0.05)$.

\begin{tabular}{lllll}
\hline Parameter & $\mathrm{NaCl}[\mathrm{mM}]$ & & & \\
& 0 & 12 & 24 & 48 \\
\hline Glucose [\% DM] & $0.24 \pm 0.01^{\mathrm{a}}$ & $0.44 \pm 0.02^{\mathrm{b}}$ & $0.56 \pm 0.02^{\mathrm{c}}$ & $0.52 \pm 0.02^{\mathrm{c}}$ \\
Fructose [\% DM] & $0.20 \pm 0.01^{\mathrm{a}}$ & $0.20 \pm 0.02^{\mathrm{a}}$ & $0.22 \pm 0.01^{\mathrm{a}}$ & $0.21 \pm 0.03^{\mathrm{a}}$ \\
Sucrose [\% DM] & $6.59 \pm 0.09^{\mathrm{b}}$ & $5.63 \pm 0.22^{\mathrm{a}}$ & $6.05 \pm 0.15^{\mathrm{a}}$ & $5.60 \pm 0.18^{\mathrm{a}}$ \\
Mannitol [\% DM] & $1.59 \pm 0.16^{\mathrm{b}}$ & $0.94 \pm 0.15^{\mathrm{a}}$ & $0.96 \pm 0.06^{\mathrm{a}}$ & $1.18 \pm 0.03^{\mathrm{a}}$ \\
Sorbitol [\% DM] & $6.31 \pm 0.22^{\mathrm{c}}$ & $4.91 \pm 0.31^{\mathrm{a}}$ & $5.63 \pm 0.32^{\mathrm{b}}$ & $5.64 \pm 0.27^{\mathrm{b}}$ \\
Total sugars [\% DM] & $14.93 \pm 0.38^{\mathrm{c}}$ & $12.12 \pm 0.60^{\mathrm{a}}$ & $13.41 \pm 0.47^{\mathrm{b}}$ & $13.13 \pm 1.05^{\mathrm{b}}$ \\
Translocated & $14.49 \pm 0.38^{\mathrm{c}}$ & $11.48 \pm 0.61^{\mathrm{a}}$ & $12.64 \pm 0.45^{\mathrm{b}}$ & $12.42 \pm 1.03^{\mathrm{b}}$ \\
Nontranslocated & $0.44 \pm 0.01^{\mathrm{a}}$ & $0.64 \pm 0.02^{\mathrm{b}}$ & $0.78 \pm 0.02^{\mathrm{c}}$ & $0.73 \pm 0.02^{\mathrm{c}}$ \\
Trans/nontrans & $32.60 \pm 0.68^{\mathrm{b}}$ & $18.00 \pm 1.36^{\mathrm{a}}$ & $16.27 \pm 0.36^{\mathrm{a}}$ & $17.20 \pm 0.99^{\mathrm{a}}$ \\
Trans/total & $0.97 \pm<0.01^{\mathrm{b}}$ & $0.95 \pm<0.01^{\mathrm{a}}$ & $0.94 \pm<0.01^{\mathrm{a}}$ & $0.94 \pm 0.01^{\mathrm{a}}$ \\
Nontrans/total & $0.03 \pm<0.01^{\mathrm{a}}$ & $0.05 \pm<0.01^{\mathrm{b}}$ & $0.06 \pm<0.01^{\mathrm{b}}$ & $0.06 \pm<0.01^{\mathrm{b}}$ \\
Starch [\% DM] & $0.14 \pm 0.01^{\mathrm{a}}$ & $0.15 \pm 0.01^{\mathrm{a}}$ & $0.14 \pm 0.01^{\mathrm{a}}$ & $0.14 \pm 0.01^{\mathrm{a}}$ \\
\hline
\end{tabular}




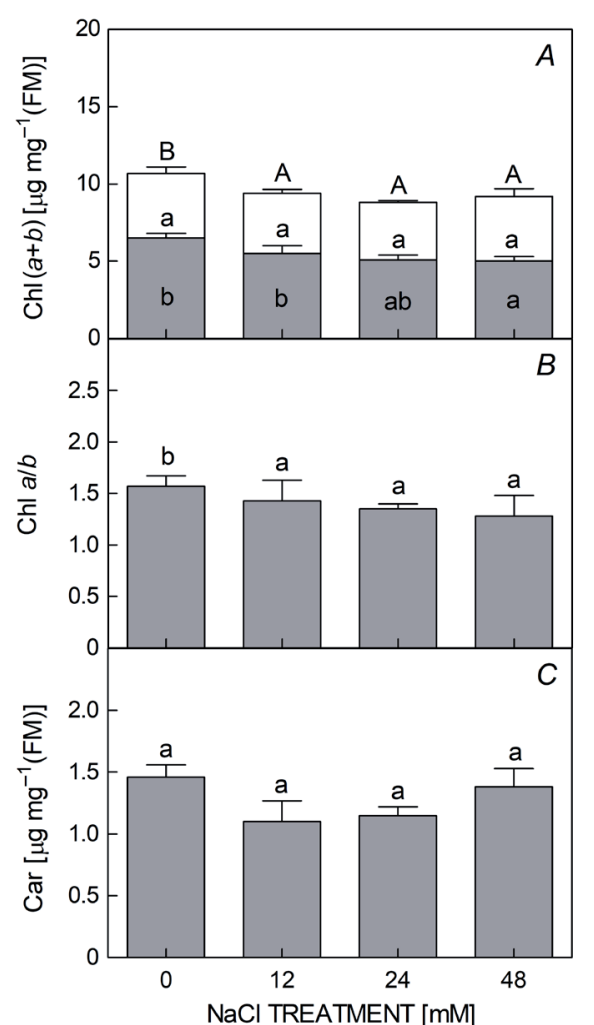

Fig. 2. Content of $(A)$ total chlorophyll $\left(\mathrm{Chl}_{\mathrm{TOT}}\right)$ as the sum of Chl $a$ (grey bar) and Chl $b$ (white bar); $(B) \mathrm{Chl} a / b$ ratio, and (C) total carotenoid (Car) in leaves of Eriobotrya japonica seedlings in relation to increasing concentrations of $\mathrm{NaCl}$ in the nutrient solution $(0,12,24$, and $48 \mathrm{mM})$. Means $(n=5 \pm \mathrm{SE})$ with similar lowercase letters are not statistically different according to multiple range Tukey's post-hoc test $(P \leq 0.05)$. Means with different capital letters indicate that averages of $\mathrm{Chl}_{\text {TOт }}$ are statistically different according to multiple range Tukey's posthoc test $(P \leq 0.05)$.

than that of controls $(+32.3,+54.4$, and $+36.7 \%$ at 12,24 , and $48 \mathrm{mM} \mathrm{NaCl}$, respectively) (Fig. 3C).

Photosynthetic parameters: Photosynthetic rate was severely constrained by salinity and the most severe reduction of $P_{\mathrm{N}}$ was observed with the highest $\mathrm{NaCl}$ concentration $(-63.1 \%)$. The decline of $P_{\mathrm{N}}$ was less severe and similar in plants grown with 12 and $24 \mathrm{mM} \mathrm{NaCl}$ ( -36.7 and $44.3 \%$, respectively) (Fig. $4 A$ ). Values of $g_{s}$ declined similarly in salt-treated plants and independently to the $\mathrm{NaCl}$ concentration that were imposed (Fig. 4B). Intrinsic WUE $\left(P_{\mathrm{N}} / g_{\mathrm{s}}\right.$; Fig. $\left.4 C\right)$ as well instantaneous WUE $\left(P_{\mathrm{N}} / E\right.$; data not shown) was similar in both controls and $12-\mathrm{mM}-\mathrm{NaCl}$-treated plants whilst lower and similar values were observed in plants treated with 24 and 48 $\mathrm{mM} \mathrm{NaCl}$. Values of $P_{\mathrm{N}} / C_{\mathrm{i}}$ declined under salinity, with the most severe reduction found in plants grown with 24 and $48 \mathrm{mM}$ of $\mathrm{NaCl}$ in the nutrient solution (-55.6 and $-66.6 \%$, respectively) (Fig. $4 D$ ).

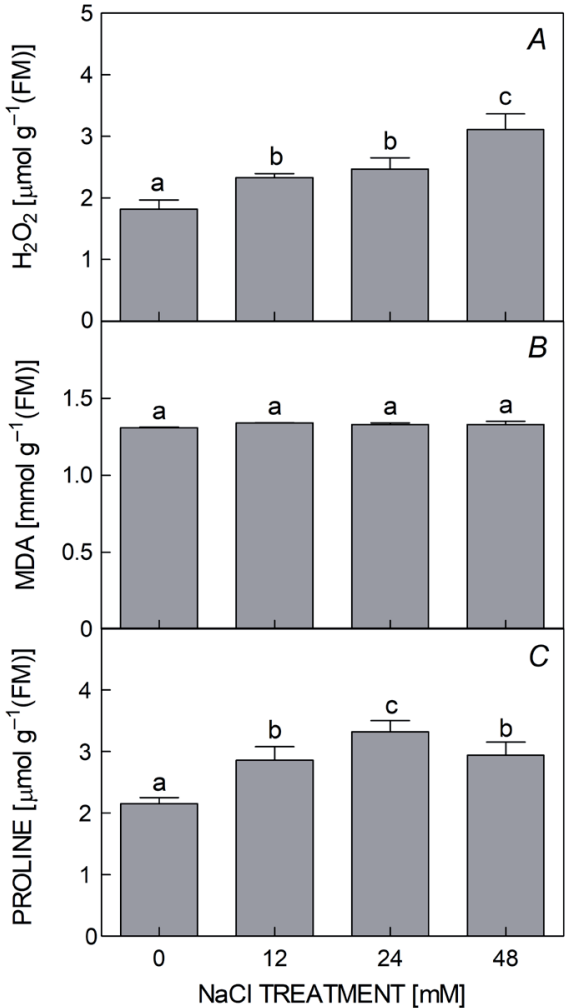

Fig. 3. Contents of $(A) \mathrm{H}_{2} \mathrm{O}_{2}$, (B) malondialdehyde byproducts (MDA), and $(C)$ proline in leaves of Eriobotrya japonica seedlings in relation to increasing concentrations of $\mathrm{NaCl}$ in the nutrient solution $(0,12,24$, and $48 \mathrm{mM})$. Means $(n=5 \pm \mathrm{SE})$ with the same letters are not statistically different according to multiple range Tukey's post-hoc test $(P \leq 0.05)$.

\section{Discussion}

One of the initial effects of salinity is the reduction of growth rate which can be observed either at whole-plant level or more evidently on specific plant organs (Parida and Das 2005, Parihar et al. 2015). The reduction of plant growth is mostly the result of the deleterious effects of root-zone salinity that induces low osmotic potential, nutritional imbalance, toxicity of $\mathrm{Na}^{+}$and/or $\mathrm{Cl}$ (and combination of these factors). In the attempt to contrast/ counteract salt-promoted effects, multiple biochemical, physiological and molecular alterations occur in planta (Munns 2002, Krasensky and Jonak 2012). Among the biometric parameters measured in the present experiments, we only observed a significant reduction of leaf area per plant in plants grown with the highest $\mathrm{NaCl}$ concentration (48 $\mathrm{mM}$ ), which was attributable to both fewer in number and smaller in size leaves per plant with respect to controls. In these plants, typical symptoms of $\mathrm{NaCl}$ toxicity (marginal leaf necrosis and necrotic patches close to the margin of the leaf, Fig. 1S, supplement) appeared in basal, older leaves (not contemplated for biochemical and physiological analyses). No symptoms were observed 


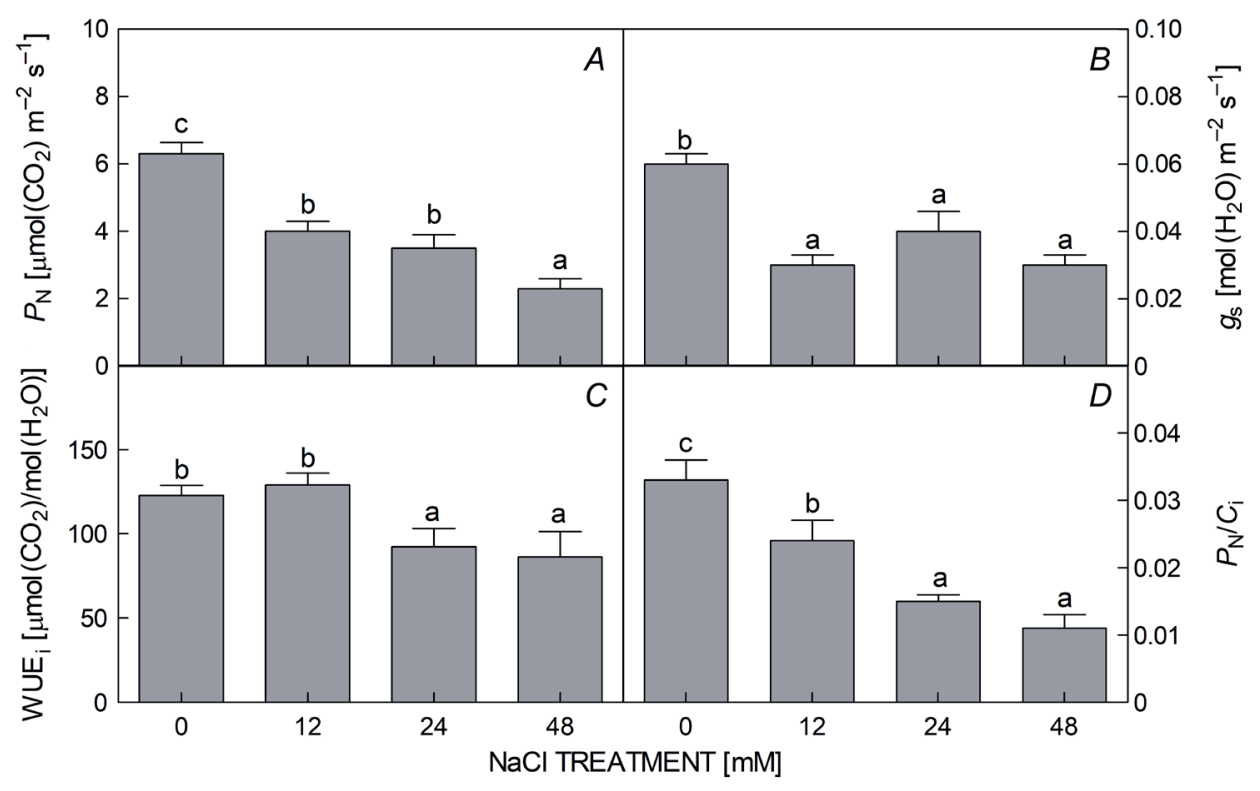

Fig. 4. $(A)$ Net photosynthesis $\left(P_{\mathrm{N}}\right),(B)$ stomatal conductance $\left(g_{\mathrm{s}}\right),(C)$ intrinsic water-use efficiency $\left(\mathrm{WUE}_{\mathrm{i}}\right)$, and $(D) \mathrm{CO}_{2}$-use efficiency $\left(P_{\mathrm{N}} / C_{\mathrm{i}}\right)$ in leaves of Eriobotrya japonica seedlings in relation to increasing concentrations of $\mathrm{NaCl}$ in the nutrient solution $(0,12,24$, and $48 \mathrm{mM})$. Means $(n=10 \pm \mathrm{SE})$ with the same letters are not statistically different according to multiple range Tukey's post-hoc test $(P \leq 0.05)$.

in leaves of plants grown with 12 and $24 \mathrm{mM} \mathrm{NaCl}$. This suggests that, at least under the experimental conditions applied in current study, loquat seedlings were able to adjust their metabolism to successfully counteract the effect of $\mathrm{NaCl}$ when the concentrations were lower than 48 $\mathrm{mM}$. Other authors have observed a more severe reduction of loquat biomass, imposing similar levels of salinity contrary to those tested in the present experiments (GarcíaLegaz et al. 2005, López-Gómez et al. 2007). However, other differences related to the experimental protocol (e.g., longer exposure, different age of plant material used and/ or different cultivation methods) make the comparison very difficult.

The maintenance of ion balance is crucial for the maintenance of plant growth under salinity because one of the main effects of salinity is the disruption of ion homeostasis (Zhu 2003). Despite its toxicity, $\mathrm{Cl}^{-}$is considered as the most detrimental factor when plants are grown in hypersaline environment. The perturbation of cation homeostasis (such as $\mathrm{K}^{+}$) caused by excessive $\mathrm{Na}^{+}$ uptake can severely perturb the plant metabolism as well (Tavakkoli et al. 2011). It is well known that $\mathrm{K}^{+}$is essential for osmoregulation and protein synthesis, maintaining cell turgor and stimulating photosynthesis (Flowers et al. 2015). In addition, both $\mathrm{K}^{+}$and $\mathrm{Ca}^{2+}$ are required for maintaining the integrity and functionality of cell membranes. In our experiment, we observed different allocation patterns of $\mathrm{Na}^{+}$and $\mathrm{Cl}^{-}$: stoichiometrically, $\mathrm{Na}^{+}$accumulated prevalently in leaves whereas the roots appeared to provide a strong barrier against $\mathrm{Cl}^{-}$, where the anion was strongly accumulated. García-Legaz et al. (2005) demonstrated that loquat grafted onto anger (Cydonia oblonga) resulted in more tolerant to high salinity due to a rootstock ability to reduce the transport of $\mathrm{Na}^{+}$and $\mathrm{Cl}^{-}$to the shoots (GarcíaLegaz et al. 2005). However, in view of the considerable accumulation of $\mathrm{Na}^{+}$and $\mathrm{Cl}^{-}$in the leaves ( 8-fold higher than controls), compartmentalization mechanisms (such as vacuole storage) are likely to assist loquat leaves once both $\mathrm{Na}^{+}$and $\mathrm{Cl}^{-}$are inexorably absorbed and translocated to the leaves (Zhu 2003).

Besides the compartmentation and accumulation of $\mathrm{Na}^{+}$and $\mathrm{Cl}^{-}$in tissues/organs, where both are less harmful for plant metabolism, ion homeostasis can be maintained by the reduced stomatal conductance, which reduces transpiration flux, resulting in lower rates of $\mathrm{Na}^{+}$and $\mathrm{Cl}^{-}$ absorption and transport. Accordingly, we found a reduction of $g_{\mathrm{s}}$ in all the salt treatments, which was considered one of the main reason of the reduced $\mathrm{CO}_{2}$ assimilation in salt-stressed plants (Chaves et al. 2009, Shabala and Munns 2012). It is plausible that the reduction of $g_{\mathrm{s}}$ was principally dependent on the severe reduction of $\mathrm{K}^{+} / \mathrm{Na}^{+}$ ratio in leaves, as observed in several other species (for a review see Chaves et al. 2009). Besides the observed stomatal limitations, other mechanisms can hamper the photosynthetic performance of loquat leaves, as demonstrated by the accumulation of intercellular $\mathrm{CO}_{2}$ (decline of $\left.P_{\mathrm{N}} / C_{\mathrm{i}}\right)$. For example, the biochemical limitation imposed by impairment of Rubisco activity (Galmés et al. 2013) or, as observed in the current experiment, the reduction of Chl content (Amirjani 2011, Chutipaijit et al. 2011) which is probably attributable to the excessive accumulation of $\mathrm{Cl}^{-}$in leaves (Tavakkoli et al. 2011), a common finding in salt-stressed plants. The higher decline of Chl $a$ than that of $\mathrm{Chl} b$ is in agreement with other studies focusing on 
salinity stress (Mane et al. 2010) and represents a mean to preserve the functionality of PSII, which is richer in Chl $a$ and more prone to photoinhibition than PSI (Tikkanen et al. 2014). We observed that salinity depressed much more the processes leading to $\mathrm{CO}_{2}$ fixation (biochemical limitations), than the influx of $\mathrm{CO}_{2}$ per se (the decrease of $P_{\mathrm{N}}$ was greater than that of $g_{\mathrm{s}}$ ), as already reported in other species (Rady 2011). This is the reason why we did not observe any WUE increment in our salt-treated seedlings, which is often a response to minimize water loss and $\mathrm{Na}^{+}$ and $\mathrm{Cl}^{-}$accumulation, as demonstrated by other authors (Yang et al. 2008, Shabala and Munns 2012).

Severe accumulation of $\mathrm{Na}^{+}$and $\mathrm{Cl}^{-}$causes osmotic stress in plant cells and can lead to the accumulation of solute compatibles, including proline, sugar, and/ or polyols (Gupta and Huang 2014, Penella et al. 2016, Guidi et al. 2017, Pompeiano et al. 2017). Enhancement of proline content caused by elevated salinity might further contribute to sustaining the electron flow between photosystems, stabilizing the redox balance, reducing photoinhibition and the level of damage to photosynthetic apparatus (Ashraf and Foolad 2007, Szabados and Savouré 2010); for example preserving Rubisco activity (Hamilton and Heckathorn 2001). Accumulation of glucose in loquat leaves is a common response of other species in reaction to salinity (Bohnert et al. 1995, Kerepesi and Galiba 2000) that can be attributed to the cleavage of sucrose in favor of simpler reducing sugars (Farrant et al. 1993). Under salt excess, glucose accumulation was likely to be dependent on both the reduction of phloem integrity as well as the sink strength of younger leaves, which negatively influences the sucrose biosynthesis by the mature (source) leaves (Lemoine et al. 2013). Similarly, and according to our results, it has been reported that salt excess has the potential to reduce the amounts of polyols load into the phloem due to the reduced sink strength of young leaves and/or the disruption of phloem integrity (Pommerrenig et al. 2007), which can also lead to hexose accumulation, at least until some other regulatory mechanisms take place to restore the balance. Apart from the role as osmoprotectant, glucose can also act as signaling molecule in plants under stress (Gupta and Kaur 2005), including salinity (Chaves et al. 2009), influencing the activation of stress-induced mechanisms (Lastdrager et al. 2014). It is well known that genes coding for enzymes involved in photosynthesis and other source activities (e.g., export of photoassimilates and nutrient mobilization) are down-regulated under high sugar availability, whereas those involved in sink activities (e.g., degradation of carbohydrates and the synthesis of storage polysaccharides, lipids, and proteins) are induced (Smith and Stitt 2007). In addition, strong accumulation of hexoses can promote a premature leaf senescence (Landi et al. 2015), and this partially explains the lower Chl $a / b$ ratio and the lower content of total $\mathrm{Chl}$ found in salttreated loquat leaves, as well as the incremented contents of $\mathrm{H}_{2} \mathrm{O}_{2}$ (Molassiotis et al. 2006, Tanou et al. 2009, Miller et al. 2010). Salinity-induced ROS formation can lead to oxidative damage to various cellular components, such as proteins, lipids, and DNA, interrupting vital cellular functions of plants, and finally provoking cellular death and necrosis (reviewed by Gupta and Huang 2014). Accumulation of $\mathrm{H}_{2} \mathrm{O}_{2}$ did not parallel the incremented content of MDA in loquat leaves, independently to the salt concentration applied in the present experiment. This suggests that the propagation of ROS and occurrence of lipid peroxidation remained confined to the leaves of high-salt-treated plants, and thus the reduction of net photosynthesis can be efficiently used as a marker for the evolution of salt-triggered effects.

To conclude, we confirm that $\mathrm{NaCl}$ significantly impairs plant photosynthetic performances of loquat seedlings, principally due to stomatal limitations aimed at reducing the concentration of accumulated $\mathrm{Na}^{+}$and $\mathrm{Cl}^{-}$into the leaves. We also pointed out that salinity alters pigment composition and sugar patterns in the leaves. In particular, the incremented $\mathrm{Chl} a / b$ ratio, associated with accumulation of glucose and fructose into the leaves suggests that $\mathrm{NaCl}$ can reduce the leaf lifespan by promoting events of early senescence in fully developed leaves. Conversely, an impairment of translocating sugars (including polyols) can seriously compromise the development of sink organs, such as young leaves and fruits. Overall, these effects pose serious concerns about the possible effect of salinity to fruit production. Further research is necessary to investigate the interplay between $\mathrm{Na}^{+}$and $\mathrm{Cl}^{-}$accumulation, photosynthesis performance, and sugar metabolism in loquat leaves subjected to $\mathrm{NaCl}$ toxicity and to understand the level at which $\mathrm{NaCl}$ stress can significantly compromise the yield of this economically important fruit species.

\section{References}

Ashraf M., Foolad M.R.: Roles of glycine betaine and proline in improving plant abiotic stress resistance. - Environ. Exp. Bot. 59: 206-216, 2007.

Amirjani M.R.: Effect of salinity stress on growth, sugar content, pigments and enzyme activity of rice. - Int. J. Bot. 7: 73-81, 2011.

Bates L.S., Waldren R.P., Teare J.D.: Rapid determination of free proline for water stress studies. - Plant Soil 39: 205-207, 1973.

Bohnert H.J., Nelson D.E, Jensen R.G.: Adaptations to environmental stresses. - Plant Cell 7: 1099-1111, 1995.

Chaves M.M., Flexas J., Pinheiro C.: Photosynthesis under drought and salt stress: regulation mechanisms from whole plant to cell. - Ann. Bot. 103: 551-560, 2009.

Chutipaijit S., Cha-um S., Sompornpailin K.: High contents of proline and anthocyanin increase protective response to salinity in Oryza sativa L. spp. indica. - Aust. J. Crop Sci. 5: 1191-1198, 2011.

Farrant J.M., Pammenter N.W., Berjak P.: Seed development in relation to desiccation tolerance: A comparison between 
desiccation-sensitive (recalcitrant) seeds of Avicennia marina and desiccation-tolerant types. - Seed Sci. Res. 3: 1-13, 1993.

Flowers T.J., Munns R., Colmer T.D.: Sodium chloride toxicity and the cellular basis of salt tolerance in halophytes. - Ann. Bot.-London 115: 419-431, 2015.

Galmés J., Aranjuelo I., Medrano H. et al.: Variation in Rubisco content and activity under variable climatic factors. Photosynth. Res. 117: 73-90, 2013.

García-Legaz M.F., López Gómez E., Mataix Beneyto J. et al.: Effects of salinity and rootstock on growth, water relations, nutrition and gas exchange of loquat. - J. Hortic. Sci. 80: 199203, 2005.

García-Legaz M.F., López-Gómez E., Mataix Beneyto J. et al.: Physiological behaviour of loquat and anger rootstocks in relation to salinity and calcium addition. - J. Plant Physiol. 165: 1049-1060, 2008.

Guidi L., Remorini D., Cotrozzi L. et al.: The harsh life of an urban tree: the effect of a single pulse of ozone in salt-stressed Quercus ilex saplings. - Tree Physiol. 37: 246-260, 2017.

Gupta A.K., Kaur N.: Sugar signalling and gene expression in relation to carbohydrate metabolism under abiotic stresses in plants. - J. Biosci. 30: 761-776, 2005.

Gupta B., Huang B.: Mechanism of salinity tolerance in plants: physiological, biochemical, and molecular characterization. Int. J. Genomics 2014: 701596, 2014.

Hamilton E.W., Heckathorn S.A.: Mitochondrial adaptations to $\mathrm{NaCl}$. Complex I is protected by anti-oxidants and small heat shock proteins, whereas Complex II is protected by proline and betaine. - Plant Physiol. 126: 1266-1274, 2001.

Heath R.L., Packer L.: Photoperoxidation in isolated chloroplasts. I. Kinetics and stoichiometry of fatty acid peroxidation. Arch. Biochem. Biophys. 125: 189-198, 1968.

Hernández J.A., Aguilar A., Portillo B. et al.: The effect of calcium on the antioxidant enzymes from salt-treated loquat and anger plants. - Funct. Plant Biol. 30: 1127-1137, 2003.

Kerepesi I., Galiba G.: Osmotic and salt stress-induced alteration in soluble carbohydrate content in wheat seedlings. - Crop Sci. 40: 482-487, 2000.

Krasensky J., Jonak C.: Drought, salt, and temperature stressinduced metabolic rearrangements and regulatory networks. - J. Exp. Bot. 63: 1593-1608, 2012.

Landi M., Benelli G.: Protecting crop species from biotic and abiotic constraints in the era of Global Change: are we ready for this challenge? - Am. J. Agric. Biol. Sci. 11: 51-53, 2016.

Landi M., Tattini M., Gould K.S.: Multiple functional roles of anthocyanins in plant-environment interactions. - Environ. Exp. Bot. 119: 4-17, 2015.

Lastdrager J., Hanson J., Smeekens S.: Sugar signals and the control of plant growth and development. - J. Exp. Bot. 65: 799-807, 2014

Lemoine R., La Camera S., Atanassova R. et al.: Source-to-sink transport of sugar and regulation by environmental factors. Frontiers Plant Sci. 24: 272, 2013.

Lichtenthaler H.K., Buschmann C.: Chlorophylls and carotenoids: measurement and characterization by UV-VIS spectroscopy. - In: Wrolstad R.E., Acree T.E., An H. et al. (ed.): Current Protocols in Food Analytical Chemistry. Pp. F4.3.1-F4.3.8. John Wiley \& Sons Inc, New York 2001.

Lin S., Huang, X., Cuevas J. et al.: Loquat: An ancient fruit crop with a promising future. - Chronica Hort. 47: 12-15, 2007.

López-Gómez E., San Juana M.A., Diaz-Vivancos P. et al.: Effect of rootstocks grafting and boron on the antioxidant systems and salinity tolerance of loquat plants (Eriobotrya japonica Lindl.). - Environ. Exp. Bot. 60: 151-158, 2007.

Mane A.V., Karadge B.A., Samant J.S.: Salinity induced changes in photosynthetic pigments and polyphenols of Cymbopogon
Nardus (L.) Rendle. - J. Chem. Pharm. Res. 2: 338-347, 2010.

Miller G., Suzuki N., Ciftci-Yilmaz S. et al.: Reactive oxygen species homeostasis and signaling during drought and salinity stresses. - Plant Cell Environ. 33: 566-589, 2010.

Molassiotis A.N., Sotiropolus T., Tanou G. et al.; Antioxidant and anatomical responses in shoot culture of the apple rootstock MM 106 treated with $\mathrm{NaCl}, \mathrm{KCl}$, mannitol or sorbitol. - Biol. Plant. 50: 331-338, 2006.

Munns R., James R.A., Läuchli A.: Approaches to increasing the salt tolerance of wheat and other cereals. - J. Exp. Bot. 57: 1025-1043, 2006

Munns R., Passioura J.B., Guo J. et al.: Water relations and leaf expansion: importance of time scale. - J. Exp. Bot. 51: 14951504, 2000.

Munns R.: Comparative physiology of salt and water stress. Plant Cell Environ. 25: 239-250, 2002.

Parida A.K., Das A.B.: Salt tolerance and salinity effects on plants: a review. - Ecotox. Environ. Safe 60: 324-349, 2005.

Parihar P., Singh S., Singh R. et al.: Effect of salinity stress on plants and its tolerance strategies: a review. - Environ. Sci. Pollut. Res. 22: 4056-4075, 2015.

Penella C., Landi M., Guidi L. et al:: Salt-tolerant rootstock increase yield of pepper under salinity through maintenance of photosynthetic performances and sink strength. - J. Plant Physiol. 193: 1-11, 2016.

Pommerrenig B., Papini-Terzi F.S., Sauer N.: Differential regulation of sorbitol and sucrose loading into the phloem of Plantago major in response to salt stress. - Plant Physiol. 144: 1029-1038, 2007.

Pompeiano A., Meloni G., Landi M. et al:: Allocation pattern, ion partitioning, and chlorophyll $a$ fluorescence in Arundo donax L. in responses to salinity stress. - Plant Biosyst. 151: 613$622,2017$.

Rady M.M.: Effect of 24-epibrassinolide on growth, yield, antioxidant system and cadmium content of bean (Phaseolus vulgaris L.) plants under salinity and cadmium stress. Scientia Hortic. 129: 232-237, 2011.

Shabala S., Munns R.: Salinity stress: physiological constraints and adaptive mechanisms. - In: Shabala S. (ed.): Plant Stress Physiology. Pp. 59-93. CABI, Wallingford, UK, 2012.

Smith A.M., Stitt M.: Coordination of carbon supply and plant growth. - Plant Cell Environ. 30: 1126-1149, 2007.

Sudhir P., Murthy S.D.S.: Effects of salt stress on basic processes of photosynthesis. - Photosynthetica 42: 481-486, 2004.

Szabados L., Savouré A.: Proline: a multifunctional amino acid. - Trends Plant Sci. 15: 89-97, 2010.

Takahashi S., Badger M.R.: Photoprotection in plants: a new light on photosystem II damage. - Trends Plant Sci. 16: 5360, 2011.

Tanou G., Molassiotis A., Diamantidis G.: Hydrogen peroxideand nitric oxide-induced systemic antioxidant prime-like activity under $\mathrm{NaCl}$-stress and stress-free conditions in citrus plants. - J. Plant Physiol. 166: 1904-1913, 2009.

Tavakkoli E., Fatehi F., Coventry S. et al.: Additive effects of $\mathrm{Na}^{+}$ and $\mathrm{Cl}^{-}$ions on barley growth under salinity stress. - J. Exp. Bot. 62: 2189-2203, 2011.

Tavakkoli E., Rengasamy P., McDonald G.K.: High concentrations of $\mathrm{Na}^{+}$and $\mathrm{Cl}^{-}$ions in soil solution have simultaneous detrimental effects on growth of faba bean under salinity stress. - J. Exp. Bot. 61: 4449-4459, 2010.

Tikkanen M., Mekala N.R., Aro E.M.: Photosystem II photoinhibition-repair cycle protects photosystem I from irreversible damage. - Biochim. Biophys. Acta 1837: 210215, 2014.

Triantaphylidès C., Havaux M.: Singlet oxygen in plants: production, detoxification and signaling. - Trends Plant Sci. 
14: 219-228, 2009.

Yang C.W., Wang P., Li C.Y. et al.: Comparison of effects of salt and alkali stresses on the growth and photosynthesis of wheat. - Photosynthetica 46: 107-114, 2008.

Vemmos S.N.: Carbohydrate content of inflorescent buds of defruited and fruiting pistachio (Pistacia vera $\mathrm{L}$ ) branches in relation to biennial bearing. - J. Hortic. Sci. Biotech. 74: 94100, 1999.

Zhu J.K.: Regulation of ion homeostasis under salt stress. - Curr. Opin. Plant Biol. 6: 441-445, 2003.

(C) The authors. This is an open access article distributed under the terms of the Creative Commons BY-NC-ND Licence. 